\title{
Social fairness and justice in the perspective of modernization Guo Xian
}

Xi'an International University, Xi'an, 710077, China.

\begin{abstract}
Keywords: modernization; society; fairness; justice
\end{abstract}
\begin{abstract}
Social justice is the core value of the pursuit of social development, various areas throughout the society, but also directly reflects the social nature of the content. According to the historical development of Marx thought and concept of fairness in our society, in view of the present situation of Chinese on social justice in all areas of society, analyze its influencing factors, put forward to improve the fairness China society, improve social equity phenomenon Chinese suggestions, provide the basis for perfecting the related management system. The fair view of contemporary Chinese society, we have to explore the true meaning of the view of social fairness from two aspects of reality and, to provide more for the realization of socialist justice The theoretical guidance. According to the actual situation of current social and economic development of our country, the attention and Study on the issues of social justice as a difficult and serious social problem. Because social justice relates to the field of more extensive, involving all aspects of the problem become more complex and numerous, will therefore achieve fairness society is a long process.
\end{abstract}

\section{Introduction}

The "public", justice, justice, comply with the law of the unity of nature and purpose; "flat", equality, balance, in dealing with all kinds of relations must follow the principles of equality and reciprocity and fairness. the concept of" social relations as the reflection of the objective existence, the connotation of justice values in different social forms in different; different social groups, different classes, different individuals, by the life of social and historical conditions, social status, class status, personal understanding ability and research methods etc. limited, tend to produce different public Flat view. The value orientation of our country's socialist fair view is mainly represent the fundamental interests of the people; to realize the harmonious development of fairness and efficiency, is the inherent requirement of Chinese society fairness doctrine, so in practice, from the right to a fair, equal opportunity, fair rules and fair distribution of the four dimensions of promoting Chinese development of socialism with Chinese characteristics.

In accordance with the historical development and social practice Chinese changes, summarizes the basic connotation of the socialist concept of justice Chinese, Marx thought with China's social justice is embodied in all areas of society for the status quo, puts forward the corresponding countermeasures and suggestions. The author of this article in accordance with the method of literature research, through historical comparative analysis. Before and after comparison on different historical stage China concept of social justice, put forward to improve the current social fairness problem.

\section{The development of social justice in China}

Advocate people's basic rights and equality in political life. The socialist new Chinese established the leadership of the working class and based on the worker peasant alliance of the people's democratic dictatorship, the people in power, so that the majority of working people have participated in the work of management of state affairs and supervision of state organs' rights is a basic content in politics to achieve social justice and equal. After the founding of new Chinese, establish the system of people's Congress and the establishment of the first constitution, from the state and political system to solve the problem of people in power, established the people's democratic regime of the constitutional status of.1949, as in the interim constitution of 5 China 
people's Political Consultative Conference The common programme, the provisions of the new Chinese political system is the system of people's Congress. Then, Mao Zedong personally led to the formulation of the Constitution in 1954, with the fundamental law of the state, and specified by the people's Congress system is China's fundamental political system. The Constitution clearly stipulates that "all power belongs to the people of People's Republic of China." the National People's Congress and local people's congresses at various levels is the people exercise state power organs. People generated by the democratically elected deputies, consisting of people's congresses at all levels. On behalf of the people exercise state power. The people's Congress system to the fundamental political system of China In the form of the establishment of the equality between people, so that all the people in the state political life to enjoy equal status.

In the economic system that means of production on a fair share. Mao Zedong believes that in private ownership condition, press the working people by capitalists, bullying and exploitation, under the conditions of socialism, the common possession of means of production, working together, the implementation of distribution according to work, you can achieve social and economic justice, the majority of working people can be get rid of poverty, common prosperity. China's first built socialist system, in the city, the implementation of public-private partnership, and handicraft cooperatives, the production data are mostly concentrated in the hands of the state, a small amount of collective ownership. Take the transformation of capitalist industry and commerce use restrictions, reform "policy, benefit Using various forms of state capitalism, the transformation of enterprises and the combination of the capitalist transformation become self reliant workers. In rural areas, the implementation of agricultural cooperation, carry out the socialist nature of the collective farm

Agricultural production cooperatives civil public ownership, the small hand over the land, belonging to the collective. Because our country in socialist construction period and the national leadership of the deviation of guiding ideology, and the misunderstanding of Marx's justice thought, an absolute "fairness first" fair view leads to the "great leap forward", "people's Commune Movement", "the Cultural Revolution" grim facts, a serious impact on our country.

\section{"Give consideration to justice" social equity view}

Adhere to distribution according to work and distribution according to production factors distribution. The principle of combining the system of distribution according to work is the socialist income distribution system envisaged by Marx, the content and the basic requirements are: those who have the ability to work with the members of the society must participate in social labor and society in accordance with the quantity and quality of social workers to provide labor to labor remuneration distribution: one who works hard work, have the ability to work, not work shall not eat. Chinese second leadership of the Communist Party with Deng Xiaoping as the representative of the Marx's theory of distribution according to work with China conditions at the time, will shift the focus of the party's work in the new historical conditions of the economic development. Next, a comprehensive exposition of the socialist principle of distribution according to work, and gradually established the priority of efficiency, taking into account the production and distribution of the principle of fairness, and combined with the practice of socialist construction to be carried out at a higher level to achieve the distribution of the sense of fairness, and he will help drive its social justice to solve the problem of the Communist Party of China.1978 in December in the third Plenary Session of the 11th CPC Central Committee after the implementation of the policy of reform and opening up, the implementation of distribution according to work, a variety of modes of distribution coexist principle, and in practice to enrich and perfect, and gradually in the distribution system reflects Jiangqinfalan Jiangyoufalie, reflects the hard work, one who works, The income, not labor can not reflect; mental and manual labor, complex labor and simple labor, skilled and unskilled labor, heavy labor and non labor difference between". in the implementation of the principle of distribution according to work requirements, the whole society should adhere to the principle of efficiency first, fairness, both to make a reasonable income distribution gap, but also to prevent the polarization. 


\section{Represents the fundamental interests of the overwhelming majority of the people of China}

The world today is undergoing extensive and profound changes, and contemporary China is undergoing extensive and profound changes. The opportunity hitherto unknown challenge, hitherto unknown, the opportunities outweigh the challenges faced by the party. This is the analysis of domestic and international environment science in our country. From the perspective of international environment of peace and development is still the theme of the times, the multi polarization of the world structure. The further development of economic globalization and the rapid development of science and technology and so on, these factors bring more opportunities to the development of Chinese. But the domestic development environment, rapid economic growth while also facing greater challenges. In the 30 years of reform and opening up, China's economic development has attracted worldwide attention to In terms of GDP growth, according to official statistics show that: in 2002 a 1979 years, the average real growth rate of GDP was 9.4\% in 1980s and 90s in the first 5 years, the average annual growth rate of more than $10 \%$.

The construction of a harmonious society and create a shared is a feature of the current China on social justice. China eighteenth National Congress of the Communist Party, party secretary Hu Jintao pointed out the need to unswervingly along the road of socialism China forward, and strive to build a well-off society. We must uphold the party's leadership, the people in power, the rule of law, to ensure that people in power as the fundamental, to enhance the vitality of the party and the country, to mobilize the enthusiasm of the people as the goal, expand socialist democracy, accelerate the construction of a socialist country under the rule of law, the development of the socialist political civilization. We should pay more attention to improve the party's style of leadership and governance, ensure Party leadership People pay more attention to the effective governance of the country; improve the democratic system, enrich the forms of democracy, ensure the people's democratic election law, democratic decision-making, democratic management and democratic supervision; pay more attention to the rule of law play an important role in national governance and social management, safeguard the unification of the country's legal system, dignity, authority, to ensure that the people enjoy extensive rights and freedoms . in accordance with the law

At present, China's social justice concept also requires the establishment of a comprehensive and coordinated sustainable development concept.

Analysis of a series of contradictions and problems in China's economic and social development, put forward the strategic idea of five plans, namely "in accordance with the development of urban and rural areas, regional development, economic and social development, harmonious development between man and nature, and domestic development and opening requirements, provide a strong institutional safeguards for the comprehensive construction of a well-off society." five co-ordination is actually the five major contradictions, is the five big problem. Among them, the imbalance in regional development, urban and rural development is not balanced, some members of society income gap imbalance is more prominent. The report of the Seventeenth Party Congress also joined the coordination between the central and local, and personal interests And the collective interests, local interests and the overall interests of the current and long-term interests, the domestic and international two overall five overall content. The concept of sustainable development is the harmonious development of human and nature, dealing with economic construction, population growth and utilization of resources, ecological environment protection, promote the whole society to go on the development of production, affluent life and sound eco civilization development path.

\section{The perspective of contemporary social justice in all fields of society}

Since the reform and opening up, China's economic growth rate is very fast, the society has made great progress, but some disharmonious phenomena still appear in our real life, such as officials of corruption, the income gap between urban and rural areas is widening, medical education housing and other areas there have been many unfair, incongruous sight and so on. These the phenomenon is 
the main factor of forming the harmonious society, but also deeply remind us of social unfairness has become we must face and solve social problems. Therefore, the construction of socialist harmonious society, the main task is to solve the social justice problem will continue to eliminate some social Fair phenomenon.

\section{The fairness issue of contemporary Chinese society in the political field}

Chinese style democracy is an innovative form of democracy, it can maximize the rights of people in power, at the same time it is also fair social security system. "China's socialist democracy is the combination of electoral democracy and deliberative democracy, respecting the majority and minority, which can fully reflect the wishes and interests of coordination and all aspects of the universality of Western democracy incomparable, inclusiveness and authenticity." overall, from a practical point of view, people's democracy and democracy in the party is constantly expanding, the basic rule of law has been slightly implemented. But at the same time, some disharmonious phenomena or different degree There is, in Chinese political corruption, corruption and other phenomena are exacerbating social inequality.

Power anomie is with the drawbacks of China's rapid economic and social development. The power of the government is the public power of the society, is also based on "people's sovereignty" based on the maintenance of basic means of social public order. Once the abuse of power, public order will be destroyed, the social justice will be trampled. Especially under the condition of socialist market economy, power is vulnerable to the temptation of the market, some power departments and staff to the power of privatization for personal gain, the power of alienation as "commodities", such acts of abuse of power so that the people are very indignant. For example, since 90s A great deal of power, "Rent-seeking" in the rapid development of the market economy and the phenomenon, and appear at this stage of land lease transfer phenomenon in the capital market "money" phenomenon and so on, these are caused by the abuse of power of social injustice. Abuse of power at the same time also consume a large number of social wealth, such as the annual public funds, bus consumption, travel consumption is amazing. These phenomena are hated by the masses, the abuse of power is actually undermines China's socialist distribution according to the principles of fairness, and these conditions can also aggravate social inequality.

\section{The fairness of the contemporary social equity view in the field of cultural education}

Hu Jintao at the National Conference on education speech pointed out: "to promote the scientific development of education, to promote fair education. Education fair is an important foundation for social justice. Adhere to the public welfare and inclusive education, to promote fair as a national basic education policy, is an important foundation to promote the social justice in the task." at present, although China's education has made great achievements, but still exist many problems, and the uneven distribution of educational resources and education hook unfair opportunities are two major problems in the field of education.

The uneven distribution of educational resources is an important factor affecting the fairness of education. At present, problems mainly due to China's education fairness is the equalization of educational problems. From the perspective of resource allocation, the essence of education fairness, is the government as the subject of the allocation of resources should be planning on National Education resources reasonable allocation ensure that all sectors relative roughly equal education groups and individuals the right to education. The vulnerable groups, countries should follow the will of public education resources from the rich to the poor principle, specifically, is the public education resources to disadvantaged children tilt, this is reality of fairness. " education resources in China is mainly manifested in the uneven distribution between urban and rural areas and the uneven distribution of educational resources, the unbalanced distribution mostly caused by the policy, it must improve and perfect the education system of our country. In addition, the education of children of migrant workers and students in the college entrance examination questions around the school because of higher the allocation of educational resources is uneven the unfair education 
problems must be given attention.

\section{Suggestions and Countermeasures for the realization of social justice in contemporary China}

The promotion of contemporary Chinese social justice realization process, we must give full play to the superiority of the socialist system, increase innovation and construction of the policy system, clarify the responsibility of the government, government plays a role in achieving social equity, but also must fully play the important role of civil society.

\section{Give full play to the superiority of the socialist system}

The realization of social justice, but also cannot do without the development and improvement of market economy. Market economy is not perfect, not perfect, will directly lead to the operation of the market internal unfair, will eventually damage to economic efficiency. The socialist market economy system is a combination of the basic system of socialism and market economy, not only with the socialist system characteristics, but also has the general characteristics of the market economy. The fundamental goal of socialism is to realize human liberation and freedom and comprehensive development, that is to say, the socialist system is to realize the maximum social fairness, in practice is to safeguard people's root The interests and the socialist market economy is the role of the market by means of liberation and development of productive forces, in order to achieve the basic purpose of socialism. Therefore, improving and developing the socialist market economy, we should not only grasp the development of the market economy and the general characteristics of common characteristics, but also grasp the socialist market economy system has been running smoothly basis. In order to avoid the market failure caused by economic and social unfairness. This requires that we must unswervingly adhere to the basic system of socialism, and on this basis to speed up the development and improvement of market economy system, give full play to the market economy The superiority of the system, so as to provide a good system to achieve social security.

\section{To play the role and responsibility of the government in the realization of social fairness}

The Chinese government is the executive organ of the state organ is the state administrative organs, management and service. Its function is an important responsibility of modern government, is to maintain social justice. "Whether people of fair view of how different people have an expectation on the government, which is an important function the government is promoting social fairness. From the present situation in our country, with the development of market economy, has made great economic achievements in our country at the same time, also appeared a series of social contradictions and problems. In the process of economic development, if the orientation of the government responsibility is not clear, it will cause negative equity the impact on society. Therefore, we must further clarify the government's responsibility to explore the role of the government to play an effective way, so that the government effectively play a role in promoting social fairness.

At present because our country is in a critical period of economic and social transformation, there are many issues of social justice and transition of government functions lag. Therefore, we must deepen the reform of the government, to promote the functions of the government from economic construction to public service to change, improve government services for economic and social development as well as the ability and level of service of the people, which is to promote sound and rapid economic development, is also an important guarantee to achieve social justice. We must believe that our government is the government serving the people, not only to actively support the work of the government, but also to monitor the behavior of the government, this is our civic and political literacy A manifestation of.

The government should according to the actual situation of current social and economic development of our country, considering the different needs between regions, between urban and rural areas, the public finance income to invest more in education, health, employment, 
environment, public infrastructure and other fields. The correct use of tax leverage to regulate good, cooperate with relevant countries to monetary policy. To guide the rational adjustment of industrial structure, optimize the allocation of resources to play the role of social, in order to promote the operation of the market fair. In addition to the urban and rural difference in fact, in the planning of fiscal expenditure, we should give priority to the construction of rural areas, to further guide the public finance to agriculture Village compulsory education, new cooperative medical care and social assistance, etc., to promote the equalization of regional, urban and rural development, and promote social equity.

\section{Play the role of civil society}

In the realization of social justice in the process, although the government plays a leading role, but the government is not only to achieve power of social justice, civil society has increasingly become an important force for the realization of social fairness. The civil society in the development of a healthy market economy when the type is indispensable. The civil society relates to all fields of social life that is mainly composed of some non governmental and non enterprise organizations, including some rights organizations, charitable organizations, voluntary organizations, community organizations and various industry associations.

\section{Conclusions}

Social justice as a core value of the socialist society and the pursuit of development, various areas throughout the China contemporary society, but also directly reflects the inherent nature of socialism. The fair view of contemporary China society, we must explore the real connotation of social justice view from two angles of reality and to provide theoretical guidance for more for the realization of socialist justice. This paper based on the classical writer Marx and the Communist Party of China equity theory, combined with the reality of social and economic development in current China, the research on the issue of social equity as a difficult and serious social problem Attention and study. Because the social justice relates to the field of more extensive, involving all aspects of the problem are very complicated and various, so the realization of social fairness will be a long process. The process of promoting social fairness, in addition to the necessary academic theory, the most important thing is the theory in the actual application. Not only the party and government should pay more attention and concern, continuously improve policies and regulations to promote the realization of social justice, and as citizens, we should be more proactive people start from the self, to actively supervise the corresponding government departments to resist unfair behavior, eliminate unfair phenomenon, In order to realize the construction of the socialist harmonious society, we can not only contribute to the construction of the socialist harmonious society, but also our society will be more sunshine.

\section{Reference}

[1] Engels Marx .(first volume) [M]. Beijing. people press, 1956.

[2] Marx Engels. (first volume) [M]. Beijing people's publishing house, 1995.

[3] Marx Engels. (third volume) [M]. Beijing people's publishing house, 1995.

[4] Hu Jintao. Hold high the great banner of socialism China to seize the comprehensive construction well-off society shinsho.Lee and struggle [M]. people press, 2007.

[5] Shi Ming. Fair distribution theory and strategy of [M]. Shanghai Academy of Social Sciences Press, 1994.

[6] Marx Engels Xu Qingpu theory and Chinese reality [M]. people's publishing house, 2007. 